\title{
Family embeddedness and entrepreneurship experience: a study of Indian migrant women entrepreneurs in Australia
}

\section{Fara Azmat \& Yuka Fujimoto}

To cite this article: Fara Azmat \& Yuka Fujimoto (2016) Family embeddedness and entrepreneurship experience: a study of Indian migrant women entrepreneurs in Australia, Entrepreneurship \& Regional Development, 28:9-10, 630-656, DOI: 10.1080/08985626.2016.1208279

To link to this article: http://dx.doi.org/10.1080/08985626.2016.1208279

\section{冓 Published online: 15 Jul 2016.}

\section{Submit your article to this journal ¿}

Џll Article views: 404

Q View related articles $\sqsubset$

View Crossmark data ¿

4 Citing articles: 1 View citing articles 지 


\title{
Family embeddedness and entrepreneurship experience: a study of Indian migrant women entrepreneurs in Australia
}

\author{
Fara Azmat ${ }^{\mathrm{a}}$ and Yuka Fujimoto ${ }^{\mathrm{b}}$ \\ ${ }^{a}$ Department of Management, Deakin University, Geelong, Australia; ${ }^{b}$ Department of Economics and \\ Management, Sunway University Business School, Sunway University, Kuala Lumpur, Malaysia
}

\begin{abstract}
India has emerged as a major source of migrants for developed countries including Australia; yet, there is a dearth of research on Indian migrant entrepreneurs, particularly women. Using qualitative methods of enquiry, we explore the perceptions of Indian migrant women entrepreneurs (MWEs) and their partners in Melbourne, Australia, about their entrepreneurship experiences from a family embeddedness perspective. More specifically, we explore how family embeddedness of Indian MWEs is influenced by certain factors which in turn influence their entrepreneurship experience. Our findings suggest that entrepreneurship among Indian MWEs is a complex phenomenon influenced by their being an Indian, a woman and a new Australian, all of which interact and influence their family dynamics and entrepreneurial experience. Our findings shed light on the duality of Indian culture which exerts both an enabling and a constraining influence on the family dynamics of MWEs, the constraining role of gender and the positive impact of their integration into the host country's sociocultural context which all influence their family embeddedness and entrepreneurship. Contributing to the discussion on 'ethnic' and 'women entrepreneurship' from a family embeddedness perspective, we offer policy implications for facilitating entrepreneurship in the growing but under-researched cohort of Indian MWEs.
\end{abstract}

\section{ARTICLE HISTORY}

Received 27 August 2015

Accepted 28 June 2016

\section{KEYWORDS}

Australia; family embeddedness; ethnic entrepreneurship; India; migrant women entrepreneurs

\section{Introduction}

In the last few decades, we have witnessed an expansion of scholarly interest in the field of women's entrepreneurship (Ahl 2006; Calas, Smircich, and Bourne 2009; Hughes et al. 2012; Chiang, Low, and Collins 2013; Gutiérrez, Fuentes, and Ariza 2014; Langevang et al. 2015). As the topic matures, scholars have stressed the need for new research directions'to capture more and richer aspects of women's entrepreneurship' (Ahl 2006, 610; Calas, Smircich, and Bourne 2009; Hughes et al. 2012; Gutiérrez, Fuentes, and Ariza 2014). For instance, authors have stressed the need for a collective focus on women entrepreneurs to enable an understanding of contextual and cultural variables rather than an individualist focus (Essers, Doorewaard, and Benschop 2013). Research further points to the need for explorative qualitative rather than analytic quantitative techniques for a more robust understanding of the 
phenomenon of women's entrepreneurship to'shed light on the actions and efforts in entrepreneurship unique to women' (Ahl 2006; Brush and Cooper 2012, 5; Hughes et al. 2012). In addition, the entrepreneurship literature has been criticized for neglecting the impact of family dynamics on entrepreneurial processes, despite family and business dynamics being highly interrelated (Aldrich and Cliff 2003; Jennings and McDougald 2007). Researchers have, therefore, been encouraged to analyse the activities of entrepreneurs within the context of their lives from a family embeddedness perspective, and incorporating family dimensions for more holistic insights (Aldrich and Cliff 2003; Jennings and McDougald 2007). Some scholars even argue that entrepreneurial studies that do not take into account family dimensions are incomplete (Jennings and McDougald 2007). Due to the interdependent and dynamic relationship between family and business (Aldrich and Cliff 2003), women entrepreneurs' family dynamics and entrepreneurial experiences are likely to be influenced by their ethnicity-led restrictions and socially constructed expectations (Amine and Staub 2009; Jamali 2009; Marlow and McAdam 2012, 118). However, despite increasing trends and evidence of self-employment and small business ownership among migrant women worldwide (Baycan-Levent 2010), migrant women entrepreneurs (MWEs) remain largely invisible and marginalized in mainstream entrepreneurship research (Collins and Low 2010; Pécoud 2010; Azmat 2013; Chiang, Low, and Collins 2013; Langevang et al. 2015). This is because the gender dimension is often ignored in the literature on ethnic entrepreneurship, while the ethnic dimensions are generally ignored in the female entrepreneurship literature (Collins and Low 2010; Verduijn and Essers 2013). Our focus on Indian MWEs adds an important ethnic perspective to the emerging literature on women entrepreneurs. We extend the scope of the women entrepreneurial research by adding the important yet overlooked dimensions of ethnicity and family embeddedness. Our findings add to the discussions on 'ethnic entrepreneurship' and 'women's entrepreneurship' by exploring the perceptions of Indian MWEs and their partners, based in Melbourne, Australia, and provide insights into the complexities of their entrepreneurship experience from a family embeddedness perspective. In this paper, we use the term family embeddedness to refer to the collection of factors that influence family dynamics of MWEs, reinforcing the interdependent and dynamic relationship between family and business.

Australia has been ranked as the second-best country in the world after the U.S. for a woman entrepreneur since 2013 (Gender-GEDI Executive Report 2013; Keating 2014; Terjesen and Lloyd 2015). The recent Global Entrepreneurship Institute study (GEDI) in 2015 also ranks Australia second after the U.S. among 77 countries for women entrepreneurs (Terjesen and Lloyd 2015). However, the experiences of ethnic women entrepreneurs in Australia remain under-researched. Our study is the first of this kind that provides an exploration of the complexities of entrepreneurship experience among Indian migrant women in Australia, from a family embeddedness perspective. Using multiple stages of data collection, we explored the entrepreneurship experiences of MWEs through the perceptions of MWEs and their partners, in the first phase of the study. As the issue of family embeddedness emerged as a prominent theme for MWEs in the first phase, reinforcing the dynamic interaction between family and business (Aldrich and Cliff 2003), we then explored their entrepreneurship experiences from a family embeddedness perspective in the second phase of the study using a group-based dialogic introspection method.

The study makes several contributions to the literature on 'ethnic entrepreneurship', 'women's entrepreneurship' and 'family embeddedness of entrepreneurs'. Combining the three 
concepts - ethnic entrepreneurship','women's entrepreneurship' and 'family embeddedness of entrepreneurs' - our findings provide both positive and negative perspectives on the phenomenon of migrant women's entrepreneurship. Our findings depict MWEs' struggles, their strong determination and passion to overcome the struggles and how their embeddedness in the sociocultural context of the host country acts as a catalyst, igniting women's motivation and feelings of personal freedom to follow their aspirations. Our empirically derived framework explains the complexity of entrepreneurship among Indian MWEs by highlighting that being an Indian, a woman and a new Australian all interact to influence women's family dynamics which, in turn, influence their entrepreneurship experience. More specifically, our findings shed light on the duality of Indian home culture which exerts both an enabling and a constraining influence on the family dynamics of MWEs, the constraining role of gender and, at the same time, the positive impact of their integration into the host country's sociocultural context, all of which interact to influence their family embeddedness and business experience. Our framework thus depicts that being an Indian, a woman and a new Australian is likely to have conflicting influences on the family dynamics and entrepreneurship experiences of MWEs. Notably, our study is complementary and builds on the findings of earlier research (Flood 2003; Pio 2007), reinforcing that certain distinctive features of Indian culture, such as strong family orientation, living in joint families and male dominance, are still prevalent, and may act either as enablers or constraints for MWEs entrepreneurship.

Second, our study highlights the significance of social embeddedness and how it dissolves the somewhat simplistic division implicit in the pull-push logic in relation to determinants of migrant women's entrepreneurship offering additional insights. Contrary to common perceptions (Ghosh and Cheruvalath 2007), our findings suggest that Indian women are mainly self-motivated (pulled) rather than forced (pushed) into entrepreneurship. We argue that MWEs' social embeddedness in Australian society has pulled them towards entrepreneurship, by helping both MWEs and their partners to change their perceptions about culturally stereotyped gender roles, and making them more aware of the rights of women. Within the context of Australia, our findings highlight the importance of social embeddedness in acting as a catalyst to facilitate the passion and aspirations of Indian MWEs for freedom and independence, and more importantly to change their partners' expectations and their perceptions about women's equality, roles and rights which all influence MWEs entrepreneurship.

Finally, in recent years, India has emerged as one of the biggest sources of migrants globally. In Australia alone, 15.7\% of immigrants from 2011 to 2012 were Indian (Lane 2014). While there have been some studies on Asian migrant male entrepreneurs in Australia (Constance et al. 1991; Stromback and Malhotra 1994), research on Asian MWEs in Australia is only emerging (Collins and Low 2010; Chiang, Low, and Collins 2013). In addition, Indian culture places a strong focus on family; however, how the family dynamics affect Indian migrant women's entrepreneurship in a Western host country with different values and beliefs has received little attention. Hence, this study on family embeddedness of Indian MWEs is a useful addition to the existing literature on Indian ethnic entrepreneurship and women's entrepreneurship. Our study is in line with the growing number of recent studies that have started to incorporate household and family as contexts for entrepreneurial activities (Welter 2011). 
The paper is organized as follows. First, we offer a critical appraisal of existing research in the field of female entrepreneurship and the role of gender in entrepreneurship. This is followed by an explication of the mixed embeddedness theory and how culture is connected to embeddedness to provide a theoretical background to our study. Next, we present our methodology followed by our findings, which has resulted in the establishment of a framework explaining the entrepreneurship experiences of Indian MWEs from a family embeddedness perspective. The paper concludes by discussing theoretical and practical implications as well as avenues for future research.

\section{Ethnicity, gender and women's entrepreneurship}

With the increasing salience and visibility of ethnic entrepreneurs globally, ethnic and migrant entrepreneurship is often recognized as contributing positively to the host nation's economic activity (Clark and Drinkwater 2010; Beckers and Blumberg 2013) as well as being a tool for immigrants' integration into the host society (Hiebert 2002; de Vries 2012). Although the terms 'ethnic entrepreneurship' and 'immigrant entrepreneurship' are often used interchangeably, there is a subtle difference between them (Volery 2007; Azmat 2010). Ethnic entrepreneurship is 'a set of connections and regular patterns of interaction among people sharing common national background or migration experiences' (Waldinger, Aldrich, and Ward 1990, 3). Ethnic entrepreneurs are self-employed individuals who self-identify, or can be identified, with a particular ethnic (geographically or religiously based) group with which they share a common origin or a common culture (Waldinger, Aldrich, and Ward 1990; Volery 2007). Immigrants, on the other hand, include individuals who have immigrated over the past few decades and exclude members of ethnic minority groups who have been living in the country for several centuries such as Afro-Americans in the U.S. and aborigines in general (Volery 2007). The term 'ethnic' is a broader concept and includes both, entrepreneurs who have been living in the country for a long time and belong to a specific group and immigrant entrepreneurs who have recently immigrated (Volery 2007). Immigrant entrepreneurship therefore refers to the early stages in the process of ethnic entrepreneurship. We use the term migrant entrepreneurs in our paper as we focus on women entrepreneurs who have immigrated over the last decade and are in the early stage of ethnic entrepreneurship.

The phenomenon of migrant women's entrepreneurship is shaped by the effects of 'gender, ethnicity/migrant' as well as the environment in which they operate (Amine and Staub 2009; Baycan-Levent 2010). Although perceptions are changing, it is widely established that women throughout the world are expected to be the primary care giver for their family and have principal responsibility for looking after children (de Bruin, Brush, and Welter 2006; Amine and Staub 2009; Marlow and Swail 2014). This persisting view of women as primary care givers affects their entrepreneurship experiences in multiple ways. First, women's family responsibilities and duties as primary carers encourage them towards part-time work, which tends to be devalued as it does not reflect the masculinized pattern of full-time employment (Marlow and McAdam 2012). Second, women are perceived as less capable as entrepreneurs because entrepreneurial actions are generally associated with men who are seen as the main bread winners for families (de Bruin, Brush, and Welter 2006; Marlow and Swail 2014). Finally, women are also reported to face varying amounts of resistance from society due to 'socially constructed expectations that they will undertake primary responsibility for domestic labour and child care' accompanied by traditional male stereotyping of women (Amine and Staub 
2009; Jamali 2009; Marlow and McAdam 2012, 118). The combination of gendered attitudes, social norms and beliefs further acts as a barrier to limit women's entrepreneurial activities (Gender-GEDI Executive Report 2013).

Although women entrepreneurs are a heterogeneous group differing in their levels of ethnicity, education, experience and networks, certain features of homogeneity relate to women entrepreneurs, regardless of where they live (Amine and Staub 2009). These include: role complexities and juggling work with family; the encountering of similar problems when they start their business; and the unique challenges faced in the local domestic market as opposed to their male counterparts (Amine and Staub 2009). Among the challenges faced by women, prominent are the problems associated with funding (de Bruin, Brush, and Welter 2006; Jamali 2009; Marlow and Swail 2014), the family-work-life balance issue (Jennings and McDougald 2007; Amine and Staub 2009; Brush and Cooper 2012), human capital constraints (Jamali 2009; Brush and Cooper 2012), negative social acceptance and perceptions about women entrepreneurs (Jamali 2009; Marlow and McAdam 2012) and their lack of social capital. These challenges also resonate with the other multi-faceted problems faced by MWEs. Research has identified multiple factors - human capital, culture, family, institutional factors, gender and social capital - as possible barriers for MWEs (Azmat 2013). MWEs also encounter gender-neutral challenges such as access to capital and restrictive government regulations and a lack of local knowledge, culture and language (Raijman and Semyonov 1997; Kantor 2002; Volery 2007; Dhaliwal, Scott, and Hussain 2010).

There is growing evidence suggesting that MWEs are the victims of 'double disadvantage' (Raijman and Semyonov 1997; Dhaliwal, Scott, and Hussain 2010) and, in some cases, even 'triple disadvantage' (Raijman and Semyonov 1997; Pio and Essers 2014), particularly if they migrate from a developing country to a developed country. While the term 'double disadvantage' refers to the problems faced by women, first as immigrants and second as women, 'triple disadvantage' adds a third dimension with respect to immigrants from developing countries (Raijman and Semyonov 1997; Azmat 2013). MWEs from developing economies are reported to be the most disadvantaged group (Raijman and Semyonov 1997) among entrepreneurs. They are more likely to find adapting to the labour markets and institutional framework of developed economies challenging, as they come from very different regulatory environments and socio-economic contexts (Drori, Honig, and Ginsberg 2006; Azmat 2010). While these challenges are faced by all immigrant entrepreneurs, they are likely to be greater for recent migrant entrepreneurs from the less-developed countries of South Asia, and Africa, and are even greater for MWEs (Azmat 2013).

Prior research also suggests that women entrepreneurs experience more prejudice in developing countries than in developed nations that results from 'deeply rooted, discriminatory, cultural values, attitudes, practices and the traditions of patriarchal culture' (Amine and Staub 2009, 192; Marlow and McAdam 2012). India has experienced a social transformation in recent decades with increased availability of education for women and more women entering into the workforce; however, research suggests that women still have a long way to go to achieve equal rights and positions (Nagadevara 2009). Deep-rooted traditions remain in India along with deeply ingrained values and beliefs that men and women are not only essentially different, but that women are inferior to men (Goyal and Parkash 2011). This has resulted in a hierarchical society where the sociological set-up is male dominated and where women are perceived as 'abla'1 and weaker in all aspects than men (Nagadevara 2009; Goyal and Parkash 2011). Such perceptions force women to lead a 
protected, dependent life, limiting their mobility and freedom, which affects their self-confidence and aspirations to run their own business (Goyal and Parkash 2011). Societal perceptions about women entrepreneurs pertaining to their family responsibilities and gender-biased culture, religion and belief systems further add to the challenges faced by women.

Increasingly, the literature on entrepreneurship emphasizes the importance of understanding the specific nature of minority groups in their host countries, given the lack of a consistent global immigrant profile (de Vries 2012). Indian immigrant entrepreneurs have been researched as an ethnic group as a result of their increasing emigration to countries such as Australia, Canada and the U.S. (Basu 1998; Dhaliwal and Kangis 2006; Pio 2007; de Vries 2007; Clark and Drinkwater 2010). Existing research in the context of Australia has provided useful insights into the obstacles faced by entrepreneurs with recognition of their overseas qualifications (Constance et al. 1991), the blocked mobility faced by Asian entrepreneurs (Stromback and Malhotra 1994) and how Asian women migrant entrepreneurs' linguistic and cultural backgrounds, as well as racism and sexism, impact their entrepreneurial experiences (Collins and Low 2010; Chiang, Low, and Collins 2013). However, research on Indian MWEs remains a largely unexplored area (Pio 2005).

\section{Mixed embeddedness theory explaining the Entrepreneurship of MWEs}

Our study draws from mixed embeddedness theory of entrepreneurship, highlighting the embeddedness of Indian MWEs in the host country's sociocultural context, and exploring the interplay between their embeddedness and their home country's culture. Identifying cultural features, specifically with regard to Indian entrepreneurs, we argue that culture, as one of the main forms of capital for entrepreneurs (Sabah, Carsrud, and Kocak 2014), is connected to and influences MWEs social embeddedness.

Among the theories that have been suggested over the years to explain the phenomenon of immigrant entrepreneurship, the theory of mixed embeddedness (Kloosterman, Van der Leun, and Rath 1999) remains prominent. Mixed embeddedness theory focuses on the embeddedness of entrepreneurs in the socio-economic and political-institutional environment of the country of settlement, and how these forces shape the opportunities of the entrepreneurs (Dana 2007). Mixed embeddedness draws attention to the range of formal and informal institutional contexts in which immigrant entrepreneurs are embedded (Kloosterman, Van der Leun, and Rath 1999; Langevang et al. 2015). The theory thus refers to the interdependence between the socio-economic characteristics of the ethnic group and their embeddedness in social networks, as well as the socio-economic and politico-institutional environment of the host country (Kloosterman, Van der Leun, and Rath 1999; de Vries 2012). It suggests that behaviours of migrant entrepreneurs in the host countries depend on their ethnic background and the host country's dynamics and context (Jack and Anderson 2002; de Vries 2012). Notably, mixed embeddedness also explains how female entrepreneurial activity is influenced by women's embeddedness in multiple and shifting institutional contexts (Welter and Smallbone 2010; Langevang et al. 2015). Our study uses the mixed embeddedness theory to explain the embeddedness of Indian MWEs in the host country's sociocultural context and how that influences their family embeddedness.

Although culture has been widely researched, the influence of home country's cultural factors, particularly deeply rooted values, beliefs, norms and traditions and their interactions 
with the entrepreneurs' embeddedness in a host society with different values, remains under-researched. A significant body of research on immigrant entrepreneurs has identified culture as one of the main forms of capital for entrepreneurs (Watts et al. 2007; Sabah, Carsrud, and Kocak 2014). The cultural resources have been identified by past research as both enablers and obstacles for MWEs (Dhaliwal and Kangis 2006; Pécoud 2010; Azmat 2013; Huggins and Thompson 2014). For example, some authors have indicated that ethnic minority businesses capitalize on cultural characteristics such as their social capital, linguistic skills, cultural knowledge and ethnic contacts to gain a competitive advantage (Kupferberg 2003; Dhaliwal and Kangis 2006; Verduijn and Essers 2013). On the contrary, some argue that racial, linguistic, religious and cultural differences act as an artificial wall immigrants need to break through before they can enter the mainstream labour market (Ensign and Robinson 2011).

Past literature has identified certain cultural features of Indian entrepreneurs, such as their focus on education, ethos and hard work, family involvement, utilization of family's social capital and finance for business start-ups, as well as their difficulty in raising institutional finance (Hamilton, Dana, and Benfell 2008; de Vries 2012). Indian migrants are also found to possess a strong cultural identity that they wish to preserve and is deeply embedded in their home country's ethnic milieu (Basu and Altinay 2002). In a similar vein, earlier research on Indian migrant women in New Zealand reports that although the Indian MWE had moved towards integration, she retained 'a strong ethnic identity while also identifying with the host society' (Pio 2005, 1280). This trend therefore suggests that Indian MWEs are likely to be influenced by their home country's culture, values and beliefs while integrating into the host society; however, the way this impacts their entrepreneurship experiences has not been researched.

Recent research has increasingly recognized that families and businesses, even though they are generally treated as naturally separate institutions, are 'inextricably intertwined' (Aldrich and Cliff 2003, 573). A large body of literature now recognizes the effect of family on work domains, illustrating how family can influence entrepreneurship through opportunity emergence and recognition, the decision to set up a new venture and access to resources. Family as a non-economic actor is increasingly being acknowledged as a 'critical factor in entrepreneurial activity in emerging economies' (Habbershon and Pistrui 2002; Sabah, Carsrud, and Kocak 2014, 306), and has received much attention in the context of family businesses (Chirico and Bau 2014; Sabah, Carsrud, and Kocak 2014) and women's entrepreneurship (Rouse and Kitching 2006; Shivani, Mukherjee, and Sharan 2006); however, its implications for MWEs have not been sufficiently explored. One of the dominant characteristics of Indian culture is the importance placed on family as a central social unit and institution. In Indian society, the concept of joint families - living with three or more generations - is seen as an 'ideal type' and is common among the élite and the higher caste (Nimkoff 2005, 73). As hierarchy is a salient feature of Indian society explained by high power distance (Singh, Zhao, and Hu 2005), it plays an important part in family structure and functionality in which seniors, particularly male figures, are given paramount authority (Budhwar, Saini, and Bhatnagar 2005). Women in such patriarchal societies are nurtured in childhood and adolescence to serve the male (Basham 2005; Essers, Doorewaard, and Benschop 2013). These values prescribing the roles and responsibilities of women are so deeply ingrained in South Asian societies that women are likely to maintain their home country's cultural roles when they settle in host countries. 
Notably, some scholars argue joint family to be a hindrance for entrepreneurial activities (Tripathi 1984) while others have found joint family to facilitate entrepreneurship (Shivani, Mukherjee, and Sharan 2006). Rouse and Kitching (2006) suggest that the family status of women entrepreneurs is a critical variable in research, as child-rearing problems contributed largely to the failure of their start-up businesses. On the contrary, the study of South Asian women entrepreneurs based in the U.K. found that the family as an institution not only supported the start-up of businesses but also provided monetary and other forms of support to enable the women to take the risk and, thus, played an important role in the success and growth of their business (Dhaliwal, Scott, and Hussain 2010). Research further suggests that globalization and sociocultural influences have caused the family system in India to change, and the concept of joint families is slowly waning (Gupta 2005; Chadda and Deb 2013). In addition, women are increasingly coming out of their traditional housekeeping roles to be represented in the labour force and are pursuing professional careers alongside men (Budhwar, Saini and Bhatnagar 2005).

Exploring the experiences of Indian MWEs, we also aim to shed insights into how social embeddedness seeks to dissolve the simplistic division implicit in the pull-push logic to explain the determinants of MWEs. Individuals are pulled towards entrepreneurship by their desire for independence, autonomy, self-achievement and self-recognition (Ensign and Robinson 2011). On the contrary, individuals, in particular increasing numbers of immigrants, are being pushed towards entrepreneurship through economic necessity, social exclusion, lack of education and skills, high levels of unemployment and language barriers, which form the main tenet of the disadvantage theory (Volery 2007; Baycan-Levent 2010; Verduijn and Essers 2013). Recently, Ghosh and Cheruvalath (2007) found that only one-fifth of women in India are drawn into entrepreneurship by pull factors; the others are forced into entrepreneurship by push factors. However, little is known about how the notions of social embeddedness influence this push-pull logic.

With the theoretical background mentioned above, we explore the entrepreneurship experiences of MWEs in the Australian host society.

\section{Methodology}

Given the link between social embeddedness and culture, we argue that the phenomenon of Indian MWEs needs to be understood from the viewpoint of their embeddedness in the sociocultural context of the host society in which they operate and their family embeddedness, which is influenced by their home country's culture. Australia has maintained its position as the second-best country for women to start businesses in the last few years since 2013 in the Gender-GEDI reports and female entrepreneurship index (FEI) report in 2015 (Terjesen and Lloyd 2015). Drawing from a 77-country study, the FEl 2015 report comprehensively analysed and identified the conditions that facilitate women entrepreneurship, focusing on certain individual-level and institutional-level dimensions and dividing them into three main sub-indices: entrepreneurial environment, entrepreneurial ecosystem and entrepreneurial aspirations. Findings report that of the 77 countries, Australia ranked second-best for women to start businesses with a total score of 74.8 on a 100 -point scale. The U.S. was ranked first with a total of 82.9 points, while India was ranked 70th with a total score of 25.3 . 
Prior research also suggests that in developing and transitional economies, starting a business is made difficult by the complexity in environmental factors which are 'hostile in social, economic and political terms' (Smallbone and Welter 2001, 261; Amine and Staub 2009). The relatively poor conditions in India compared with those in Australia, to facilitate women entrepreneurship, are further confirmed in the findings of the GEM report, which shows Australia has a higher level of Total Early Stage Entrepreneurial Activities and established business activities than other countries in the Asia-Oceania region (Kelley et al. 2014). In Australia, women entrepreneurs are twice as likely to compete in business services and exhibit high innovation levels compared to the average for the region (Kelley et al. 2014, 123). In contrast, despite many innovative women entrepreneurs, India shows low levels of women entrepreneurial activities in all phases of entrepreneurship (Kelley et al. 2014, 83).

Australia has had one of the largest intakes of immigrants in the post-1945 period. Australia's socio-economic context, its focus on supporting women's advancement and empowerment, its emphasis on multiculturalism and the number of migrant businesses add to its uniqueness. While states in Australia are not 'perfect' in terms of women's rights, and are dealing with problems of violence against women and the existence of glass ceilings, the successive waves of feminism in Australia have made significant positive impacts on women's lives (Lake 1999; State Library of Victoria 2015). Today, women in all states of Australia are generally recognized in all spheres - economic, social, cultural and political and enjoy freedom, have more choices and are becoming better represented in the highest positions in politics and business (Azmat and Rentschler 2015; State Library of Victoria 2015). Therefore, the Australian context makes it a better place for women entrepreneurs than many other countries, particularly India, where despite major ongoing achievements changing women's position in society, women are still considered inferior to men and are subject to exploitation and subjugation (Nagadevara 2009).

\section{Sample}

Sequential data collection strategies were used in an iterative process whereby the data collected in one phase contributed to the data collected in the next phase. We used qualitative methods encompassing semi-structured interviews in the first phase and a groupbased dialogic introspection method in the second phase to explore the experiences of MWEs. As we were dealing with soft issues that are not amenable to quantification (Jack and Anderson 2002), a qualitative approach was deemed appropriate. The semi-structured interviews brought ethnic women to the centre, viewing them as subjects with 'free minds' capable of telling the stories of their personal experiences (Collins 1991; Chiang, Low, and Collins 2013). Further, in order to get more balanced and holistic insights into the entrepreneurship experiences of women and to cross-validate data, we conducted semi-structured interviews with their partners as well. The interviews with the partners provided us with the opportunity to 'hear their side of the story' and capture different dimensions of the same issue, providing interesting insights which, in many cases, differed from the MWEs' narratives. We interviewed 23 participants - 15 women entrepreneurs and 8 partners - in the first stage of the study (see Table 1).

Table 1 shows the stages of the data collection process. We used purposive sampling to approach Indian MWEs through a community network. The four criteria for recruiting the MWEs were: (a) being a permanent resident; (b) having lived in Australia for at least a year 
Table 1. Stages and processes of the study.

\begin{tabular}{|c|c|c|c|}
\hline Stage/year & Process & No. of participants & Purpose \\
\hline \multirow[t]{2}{*}{ First 2012} & $\begin{array}{l}\text { Semi-structured interviews } \\
\text { done sequentially }\end{array}$ & $\begin{array}{l}15 \text { MWEs participated in } \\
\text { the interviews }\end{array}$ & $\begin{array}{l}\text { Structured part of the interview } \\
\text { gathered basic information on: (a) } \\
\text { demographic information; (b) } \\
\text { determinants; (c) barriers; and (d) } \\
\text { facilitators of women's entrepreneur- } \\
\text { ship. The purpose of the demo- } \\
\text { graphic information was to provide } \\
\text { insights to understand each } \\
\text { women's specific context and unique } \\
\text { circumstances to make better sense } \\
\text { of our findings. In addition, it also } \\
\text { helped us in designing follow-up } \\
\text { interview questions }\end{array}$ \\
\hline & & $\begin{array}{l}8 \text { partners of these } \\
\text { women were also } \\
\text { interviewed. }\end{array}$ & $\begin{array}{l}\text { Interviews were used to further probe } \\
\text { and elaborate on emerging themes } \\
\text { in the structured part of the } \\
\text { interview (Guba and Lincoln 1981) }\end{array}$ \\
\hline Second 2012-2013 & Follow-up focus group & $\begin{array}{l}4 \text { couples } \\
2 \text { couples were } \\
\text { previously interviewed; } \\
\text { two couples were new }\end{array}$ & $\begin{array}{l}\text { Based on the method of group-based } \\
\text { dialogic introspection, we asked } \\
\text { 'how being an entrepreneur is being } \\
\text { affected by their family dynamics' } \\
\text { and vice versa }\end{array}$ \\
\hline
\end{tabular}

at the time of the research; (c) being first-generation migrants; and (d) living with partners or children. As our research focused on unravelling the effect of home country's culture on their entrepreneurship experience, first-generation migrants were considered appropriate as they are more likely to be influenced by their home culture than second-generation migrants (Dhaliwal and Kangis 2006; Azmat 2010; de Vries 2012; Beckers and Blumberg 2013).

\section{Process}

In the first phase, we collected semi-structured, in-depth interviews of the participants (see Table 1). A section of the interview had closed-ended questions requiring participants to provide information on: (a) personal demographics; (b) entrepreneurship determinants; (c) barriers; and (d) facilitators of successful entrepreneurship in order to explore key factors pertaining to their entrepreneurship experiences. This initial exploration provided insights to help understand each woman's specific context and unique circumstances and to make better sense of our findings. In addition, it also helped us with designing follow-up interview questions and to come up with common experiential theme for the group-based dialogic introspection method in the second phase. We allowed participants to respond to the closedended questions in their own time. This not only offered flexibility to the participants, but also provided the researchers the time to review and analyse the results and tailor the subsequent in-depth, semi-structured questions and to explore interesting or ambiguous responses. We asked questions such as

What prompted you to be an entrepreneur? Was it an easy decision for you? Did you get your family's/partner's support in this? What are the main barriers you have faced in establishing your business? How has your gender - being a woman - affected your entrepreneurship experience? In order to receive a holistic view of the phenomenon of migrant women's entrepreneurship, we interviewed the women entrepreneurs' partners as well. We asked the partners questions such as 
Do you support your wife's/partner's involvement in the business? If, yes, how? What are your reasons for supporting her entrepreneurship? Has your wife's/partner's entrepreneurial business faced any challenges or barriers? If, yes, what are they? How has her gender - being a woman - affected her entrepreneurship experience?

In the second phase, we conducted group-based dialogic introspection with two focus groups - one for the MWEs and the other for their partners. Four couples participated in this phase. The group-based dialogic introspection method (Witt 2010) is a qualitative methodology using a search-and-find process on a common experiential topic among participants (Kleining and Burkart 2001; Witt 2010). As 'family' repeatedly emerged as a prominent theme in the interviews, we explored further by asking the MWEs and their partners a question related to family, as per the requirements of group-based dialogic introspection. To the MWEs, we asked: Please share your lived experience as an entrepreneur and how that has been affected by your responsibilities towards family? We asked the partners: How do you think your partner's lived experience as an entrepreneur has been affected by her family dynamics?

We conducted group-based dialogic introspection using the following steps: (1) we selected one question (as mentioned above) based on a common experiential topic on family; (2) we recorded introspection by each participant, that is an examination of his or her own conscious thoughts and feelings, and took notes for approximately 5-10 min in relation to the question; (3) we asked each participant to share his or her experience in turn; (4) we recorded introspection by each participant taking notes for another 5-10 min based on the collective sharing; and (5) we asked each participant to participate in a second round of sharing his or her experience. The whole process of group-based dialogic introspection was audio recorded, with the permission of the participants.

\section{Data analysis}

Two coders analysed the women's and their partners' interview data separately, and identified common content categories using coding procedures. The goal was to find emerging themes in the data by identifying and categorizing patterns (Guba and Lincoln 1981; Miles and Huberman 1994). For the group-based dialogic introspection, the recording of each focus group was analysed to find visible patterns and to develop major themes by analysing similarities and differences and identifying and categorizing patterns in the data (Guba and Lincoln 1981; Miles and Huberman 1994). The frequency of the codes appearing in each theme was also discussed by both coders to provide insights into the significant issues.

\section{Demographic}

All the MWEs were running small businesses with their number of employees ranging from 0 to 11. Table 2 provides relevant details of the women entrepreneurs. Among the $15 \mathrm{MWEs}$, 10 women were engaged in a woman-specific industry such as a beauty salon, childcare and retailing; the remaining five were involved in businesses that were not women specific, such as software freelancing, solar panel sales, legal outsourcing, web designing and stock market trading. These findings are in line with previous research which suggests that generally migrant women venture into women-specific industries such as childcare and retailing, which limit their career opportunities (de Vries 2012; Azmat 2013). As shown in Table 2, the MWEs in our sample were all educated with an undergraduate degree; six of them had a 
Table 2. Characteristics of the sample.

\begin{tabular}{|c|c|c|c|c|c|c|c|c|c|c|}
\hline No. & $\begin{array}{l}\text { Nature of } \\
\text { enter- } \\
\text { prise }\end{array}$ & $\begin{array}{c}\text { Num- } \\
\text { ber of } \\
\text { employee }\end{array}$ & $\begin{array}{l}\text { Age of } \\
\text { busi- } \\
\text { ness }\end{array}$ & $\begin{array}{l}\text { Age } \\
\text { of the } \\
\text { entre- } \\
\text { pre- } \\
\text { neur }\end{array}$ & $\begin{array}{l}\text { Educa- } \\
\text { tional } \\
\text { qualifi- } \\
\text { cations }\end{array}$ & $\begin{array}{c}\text { Marital } \\
\text { status }\end{array}$ & $\begin{array}{c}\text { No of } \\
\text { children }\end{array}$ & $\begin{array}{l}\text { Living } \\
\text { in joint } \\
\text { family }\end{array}$ & $\begin{array}{c}\text { Years in } \\
\text { Aus- } \\
\text { tralia }\end{array}$ & $\begin{array}{c}\text { Experi- } \\
\text { ence in } \\
\text { busi- } \\
\text { ness } \\
\text { (years) }\end{array}$ \\
\hline 1 & $\begin{array}{c}\text { Temporary } \\
\text { tattoos } \\
\text { (Henna) }\end{array}$ & 3 & 7 & 32 & $\begin{array}{c}\text { Under- } \\
\text { grad }\end{array}$ & Divorced & 2 & Yes & 7.5 & 7 \\
\hline 2 & $\begin{array}{l}\text { Beauty } \\
\text { salon }\end{array}$ & 4 & 15 & 40 & $\begin{array}{c}\text { Under- } \\
\text { grad }\end{array}$ & Married & 3 & No & 20 & 15 \\
\hline 3 & $\begin{array}{l}\text { Retail } \\
\text { (7-11 } \\
\text { shop) }\end{array}$ & 4 & 6 & 25 & $\begin{array}{l}\text { Under- } \\
\text { grad }\end{array}$ & Single & 0 & No & 6 & 4 \\
\hline 4 & $\begin{array}{l}\text { Web } \\
\text { design }\end{array}$ & 1 & 1 & 29 & $\begin{array}{l}\text { Post } \\
\text { Grad }\end{array}$ & Married & 0 & No & $5+$ & 1 \\
\hline 5 & Retail & 2 & 3 & 28 & $\begin{array}{l}\text { Under } \\
\text { grad }\end{array}$ & Married & 1 & Yes & 5 & 3 \\
\hline 6 & $\begin{array}{l}\text { Commer- } \\
\text { cial } \\
\text { cleaning }\end{array}$ & 11 & 2 & 25 & $\begin{array}{l}\text { Post } \\
\text { grad }\end{array}$ & Married & 0 & Yes & 4 & 2 \\
\hline 7 & Retail & 1 & 5 & 49 & $\begin{array}{l}\text { Under- } \\
\text { grad }\end{array}$ & Married & 2 & No & 8 & 5 \\
\hline 8 & $\begin{array}{l}\text { Selling } \\
\text { solar } \\
\text { panels }\end{array}$ & 7 & 1.5 & 30 & $\begin{array}{l}\text { Post } \\
\text { Grad }\end{array}$ & Married & 1 & No & $3+$ & 3 \\
\hline 9 & $\begin{array}{l}\text { Software } \\
\text { freelanc- } \\
\text { ing }\end{array}$ & 3 & 4 & 34 & $\begin{array}{l}\text { Post } \\
\text { Grad }\end{array}$ & Married & 2 & No & 9 & 7 \\
\hline 10 & Retail & - & 4 & 29 & $\begin{array}{l}\text { Post } \\
\text { Grad }\end{array}$ & Married & 1 & Yes & 11 & 4 \\
\hline 11 & $\begin{array}{l}\text { Legal } \\
\text { out- } \\
\text { sourcing }\end{array}$ & 5 & 2 & 30 & $\begin{array}{l}\text { Post } \\
\text { Grad }\end{array}$ & Married & 1 & Yes & 5 & 4 \\
\hline 12 & $\begin{array}{l}\text { Stock } \\
\text { market } \\
\text { trader }\end{array}$ & - & 3 & 48 & $\begin{array}{l}\text { Under- } \\
\text { grad }\end{array}$ & Married & 2 & Yes & 20 & 3 \\
\hline 13 & Childcare & - & 1 & 29 & $\begin{array}{l}\text { Under- } \\
\text { grad }\end{array}$ & Married & 1 & No & 3.5 & 1 \\
\hline 14 & Childcare & - & 1 & 34 & $\begin{array}{l}\text { Under- } \\
\text { grad }\end{array}$ & Married & 1 & Yes & 2 & 1 \\
\hline 15 & $\begin{array}{r}\text { Beauty } \\
\text { salon }\end{array}$ & 1 & 10 & 30 & $\begin{array}{c}\text { Under- } \\
\text { grad }\end{array}$ & Married & 1 & Yes & 13 & 5 \\
\hline
\end{tabular}

postgraduate degree. Although all MWEs except one were married, only three had no children. Among our sample, eight participants were living in a joint family with extended family members such as parents and parents-in-law.

\section{Findings}

Our findings confirm entrepreneurship among Indian migrant women to be a complex and multi-faceted phenomenon, strongly influenced by their (a) being an Indian; (b) being a woman; and (c) being a new Australian, resulting in three major themes, as discussed below. Being an 'Indian' and being 'a woman' are interrelated, yet they do have subtle differences. The former relates to the influence of ethnicity while the later relates to the influence of gender on MWEs' entrepreneurship experiences. Although Indian culture has a profound influence on gender roles with strictly prescribed expectations, MWEs do face a combination 
of unique challenges because of their gender. These challenges include lack of social networks and experiences, the family-work-life balance issue and negative social acceptance and perceptions about women entrepreneurs (Jamali 2009; Marlow and McAdam 2012) which are also confirmed in our findings.

\section{The influence of being an 'Indian' on family embeddedness and entrepreneurship experience}

'Our priority should be on family orientation as family always is first' was a common statement shared both by men and women in our sample. The strong family orientation and family-first attitude that emerged in our findings are in line with the principles of collectivism in Indian culture that have been suggested in earlier research. Family orientation and giving priority to family may be common in other nationalities as well; however, in our sample, the distinctive features of strictly expected gender roles - particularly the prescribed role and responsibility of women to 'look after the family', 'make the family happy' and 'make sacrifices for the family' - emerged as a major construct of Indian culture, which led to the commonly accepted practice of 'living in a joint family'.

The concept of living in a'joint family' with extended family members, particularly in-laws, was practised by more than half of the participants. Further, in line with the concept of a joint family, the participants who were living independently were receiving or planning to get help from their parents overseas to look after their child rather than using childcare services. The following extract illustrates the issues of 'relying on parents' help':

We thought about that, and we decided that we will call our parents. Six months for my parents and six months for her parents. (FG men)

Findings suggest that the influence of Indian cultural values on MWEs and their partners was reflected in their strong family orientation. Living in joint families acted as both a positive and/or a negative force for MWEs, which is in line with previous studies (Dhawan 2005; Azmat 2013). In our data, 4 out of 15 MWEs cited family as a barrier and 9 cited it as an enabler, with accounts of families acting as facilitators appearing more frequently in our data from both the women and their partners. The following accounts from MWEs confirm the facilitating role of the family:

Aww yes! I did have family support. In fact, my family was ... there to back me up. Aww, all the time it was my husband and my mother-in-law. They were strength at that point of time.

(Participant 14)

In our sample, the family support ranged from assistance in securing finance to help in business and support with household responsibilities, which freed the MWEs to concentrate on their business. Among the support, the help in looking after household responsibilities was seen as more crucial by the MWEs. The case of 48-year-old Participant 12 is representative. Participant 12 has been living in Australia for 20 years and started her stock market business 3 years ago. She is the sole owner and has no previous experience of running a business. As a mother, living in a joint family with her parents-in-law, works to her advantage as she is able to concentrate more on her work:

I don't need to put my kids in day care so they stay with my parents-in-law. I don't need to worry about picking them on time and whether or not they have eaten, as such things are taken care of so I can concentrate on my work, and I feel good about it. (Participant 12) 
Interestingly, in some cases, the partners presented a different view from the MWEs, which again reinforces the gendered expectation of women's family responsibilities and the lower expectations of men's family responsibilities. For example, the partner of Participant 12 (above) had very different perceptions. As a strong believer in women being responsible for all the household work, he felt that his wife'neglected household responsibilities', and relied too much on his parents, especially in taking care of their children. For example, he explained:

She can leave anytime knowing that my parents are still home and they are going to take care of the kids, take them to school or bring them from school or take them to sports or any extra-curricular activities. But the thing is that she should not take this for granted. Parents need to rest as well and they need their own time and space. (Partner of Participant 12)

Similarly, reinforcing the gendered expectation of women's family responsibilities, the partner of Participant 6 argued:

It's really important for the wife to take care of the child and also look after the house. (Partner of Participant 6)

In addition to the expectations that women undertake family responsibilities, we also found that the joint family context can present unique circumstances for MWEs, requiring them to juggle work and family domains. Living in joint families was also reported to compound the tensions in the daily lives of women, given their strictly prescribed family and other household responsibilities, regardless of their own business. For some MWEs, the concept of living in a joint family surfaced as an additional burden. The case of 49-year-old Participant 7 illustrates this. She migrated to Australia 8 years ago and started her retail business 5 years ago. Living in a joint family along with her two children has been challenging for her in terms of looking after the extended family members, doing the household work, sharing the car and working in her business, as can be seen in the quote below:

My husband's uncle, aunt and their son and we all live together in a joint family. I had their little son to take care of like my own kid, so, like almost having a kid, so travelling around, picking him at uni, cooking and housework and then handling my own business. So, having to do so many jobs and then having my own business, family did have a bit of a question as to how hard would it be, but I suppose I had to do it so I did it. (Participant 7)

In contrast, her partner commented on the joint family situation in a positive light, implying his ignorance or oversight of his wife's struggles in coping with the joint family:

We are in a joint family because we want it that way and we love it that way. (Partner of Participant 7)

In some cases, the view that women are 'inferior to men' also emerged among the MWEs, creating unique challenges for them. This is explained further in the comments of Participant 10, who works in a retail business:

Coming from India where women are still considered a little below men when you look the status. So it was quite challenging to get my parents to agree in the first place, for me to start my own business and to be working with men and be out of home working late in the nights sometimes because it's a retail business. (Participant 10)

The perception of women being inferior to men also emerged in the narratives of participants 1, 3, 5 and 6. For example, 25-year-old Participant 6, who migrated to Australia four years ago, has been successfully running a commercial cleaning business with 11 employees for two years, despite not getting enough support from her family. She talked about how she had to deal with different challenges, the lack of a social network, securing finance, family commitments and, most importantly, the negative perceptions of the family members 
who do not place as much importance on her work as they do on her partner's. Attributing this inequity in perceptions, which regards women as 'inferior', to the predominant cultural perception and beliefs, she explained:

If both husband and wife are working, husband's work is considered more important, that's commonly the thought; quite often my business is not given priority by my family members as compared to my partner's. So it's always me, who has to cancel work appointments for my family commitment.

The quotes above support the findings of earlier studies about Indian society being male dominated, and one where women are considered less important and the weaker gender which is dependent on men (Nagadevara 2009; Goyal and Parkash 2011). Such perceptions merely create additional barriers for women who run their own business ventures.

\section{The influence of being a 'Woman' on family embeddedeness and entrepreneurship experience}

Our findings suggest that MWEs face a combination of unique challenges because of their gender. Some of these challenges are faced by women entrepreneurs throughout the world, but some were specific to Indian women, suggesting the influence of Indian culture on gender roles. We found that both the men and the MWEs had strong perceptions about women's roles and responsibilities as prescribed by their culture. Gender roles prescribing the roles and responsibilities of women to look after the family are common across the globe; however, in developed countries, the concept of role-sharing - where men share the household work with women - is becoming more common in the interests of a better work/life balance (Shelton 2006; Jennings and McDougald 2007). However, in our sample, there was a strong perception among the majority of MWEs and their partners that women should 'meet all the family role commitments' and respond to all demands to make 'the family happy' and also 'make sacrifices' if needed. The following quotes from MWEs and their partners confirm their strong belief about a woman's role as a home-maker and taking care of the family which, for some women, acted as a barrier for their entrepreneurial dreams:

My wife had to stop her work for a year when she gave birth; she had to look after the baby as we didn't want to use the childcare services. It was difficult for her to come back to work, but she was happy to make this sacrifice as it was her responsibility. (FG men)

It's always man entrepreneur, have you ever seen a woman entrepreneur ... ? They are some disadvantages, for a woman being an entrepreneur, because a woman cannot really leave her personal life behind, especially if she has a family. (Participant 6)

Although there was evidence of support provided by partners, our data also suggest that a partner's support was contingent upon household responsibilities being done adequately by MWEs, which again reinforces the 'family first' attitude and the strictly prescribed role of women to look after household affairs. This perception is confirmed in the quotes below:

But, as far as everything at home is good, I am more than happy to support her in her achievement and business. (Partner 12)

I don't like to see housework being neglected or taken for granted for her business and her own work. Somehow, I still support her but at the back of my mind, it is always house and family first. (Partner 6) 
There was also a perception among MWEs who did not have children that things would change over time when they become mothers. For example, 29-year-old Participant 4, who was an expectant mother and had been running a web design business for a year, thought that although her partner was currently supportive, once the baby is born, he expected her to 'work from home and look after the baby', making it clear that he will support her only if she'works on her business in the time left after finishing all the family responsibility and domestic chores'. These perceptions were also shared by Participant 8, who explained how her circumstances had changed following the birth of her baby, complaining that her partner was no longer supportive since the birth of her child and expected her to 'quit and give $100 \%$ to the baby and family'. Such perceptions further reinforce the gendered role of women.

Our findings further suggest that some of the other challenges MWEs face are a result of the negative social perceptions and attitudes in India about the capabilities of women to run their own business. In our sample, for some MWEs, their family was over-protective and lacked confidence in them. For example, Participant 5, who had been living in Australia for five years and running a retail business for a year, narrated how as a woman, the family members are very protective towards her, requiring her to be back home before sunset which affected her business. 'I need to listen to them', she said. Expressing her frustration on how she is seen as unable to be out on her own, she complained:

It's always a challenge to be an entrepreneur or enter into this world where we are from a culture where women don't work rather stay home. I don't understand why my parents and my family does not believe the fact that I will be safe. They are always very protective which really gets annoying and gets in my way and I get really frustrated.

The following quote from one partner reinforces this attitude:

Being from the Indian background, we have lot of preconceived notions whether the woman is capable of running a business like a man. It was bit hard to expect whether she would be able to manage it and you have all these questions, that it's a big risk and too much commitment. (Partner 7)

Our findings thus suggest that the strictly prescribed expectations of the gender roles and responsibilities of MWEs are further influenced by their being Indian. The cultural perception of women to be weaker and inferior, as well as the domination of males in Indian society, together contributes to the lack of confidence and negative social perceptions about women entrepreneurs.

Despite their accent problems and lack of familiarity with the local culture and language, and the lack of social networks and experiences, the women entrepreneurs faced these challenges with hard work and passion. The following quotes describe some of the barriers faced by MWEs as women, which are consistent with the findings of prior research (Volery 2007; Baycan-Levent 2010).

Not knowing the Australian culture and the society were the barriers that I faced in establishing my business and communicating with the Australian people. (Participant 1)

One of the biggest hassle or barrier I had was no social network. When you come from overseas different countries, you should have some special network for you to sell your projects or get some more customers. (Participant 6)

However, the women's stories show that they were able to overcome barriers with passion and hard work. 


\section{The influence of being a 'new Australian' on family embeddedness and entrepreneurship experience}

An interesting dynamic that emerged from the findings is the gradually changing perceptions, both of men and women, particularly in relation to sharing household duties which were previously solely viewed as women's responsibilities. Our findings suggest that the change in perceptions about women's responsibilities is a result of both MWEs' and their partners' integration and embeddedness into the host country's culture as an Australian. This is in line with the earlier work of Pio (2005) who found Indian women entrepreneurs in New Zealand were moving towards integration and a bicultural identity. The following quotes from the partners illustrate their changing perceptions:

See, we are from Asian background and in our country we don't see women being an entrepreneur and working. They have always been a housewife, but when my wife came down here and started working alone showing the basic things that, yes, we are capable of doing it. I felt we certainly were thinking wrong and we should support them. (Partner 14)

We have to finish our dinner before $7.30 \mathrm{pm}$, so, whoever comes first starts cooking. If she came late around 6.30 and I come home around 5.30, so I start cooking. (FG men)

The changing perceptions of men were also supported by MWEs who spoke about their changing attitudes, their attempts at integration and being part of Australian society:

But here, our spouse help; even my husband looks after kids sometimes, everyone takes care of each other. (FG women)

If I was living back home, the expectation would be that I would do cooking and all the household work, but I am here and I live here and I live very much as per the Australian society so we share our duties. (FG women)

The above quotes illustrate the embeddedness of the MWEs in the Australian sociocultural context, facilitating the freedom and autonomy of women to pursue their dreams and aspirations while not being held back by prescribed gendered roles and responsibilities and negative social perceptions. By being embedded in the Australian sociocultural context, women and their partners appeared to be conscious of the concepts of role-sharing and women's contribution to society and being treated equally, and were applying these concepts in their lives.

The majority of the women in our sample were thus pulled rather than pushed into entrepreneurship which can be attributed mainly to their embeddedness in the host society of Australia. This finding is in contrast to earlier research that suggests the majority of women in India are drawn into entrepreneurship by push factors (Ghosh and Cheruvalath 2007). In our sample, women talked about their dream, passion and autonomy (pull factors) as the major reasons for being an entrepreneur. Majority (9 out of 15) of the MWEs reported autonomy and independence as their underlying reasons for being an entrepreneur, followed by 3 who cited financial reasons; and the remaining 3 were pushed into entrepreneurship because they had struggled to find a job. However, almost all the women interviewed stated that 'autonomy and independence' and 'passion' were their main driving forces for being an entrepreneur, implying the likely influence of the Australian sociocultural context in which they were embedded. The MWEs further mentioned that, although they had passion and desire for autonomy and independence back in India as well, they found it hard to'materialise their entrepreneurial dreams as the environment was just not supportive'. They faced stereotyped perceptions about women being homebound and were seen by society as 'incapable 
of running a business on their own' as well as by their family. In our sample, this opinion is reflected in the narratives of Participants, 1, 3, 5, 6 and 10. However, in Australia, they were able to pursue their motivations and aspirations for entrepreneurial dreams. The MWEs, however, mentioned that even in the context of Australian society, the attributes of motivation and passion were seen as 'essential' to deal with the obstacles created by family:

Self-motivation is the most important factor because if you have got a family saying 'no' all the time and not letting you be yourself, then you have to be self-motivated. There has to be something coming from inside you telling you to do the right thing. That's self-motivation. (Participant 5)

The prevalence of pull factors among the MWEs, as demonstrated by their passion and strong desire for autonomy, freedom and independence, may be explained by their aspiration to break away from the restrictions imposed by home country's cultural norms that limited their autonomy and imposed rigid responsibilities. In addition, our findings suggest that the sociocultural context in Australia allowing women to make their own choices, be independent and have greater control of their lives, also influenced them to be pulled towards entrepreneurship.

\section{Discussion and conclusion}

Although migrant entrepreneurship has attracted considerable attention, the ways in which the entrepreneurship experience of migrants in a host society is influenced by their family embeddedness have received little attention. Even less research exists on MWEs. Extending the discussion on 'ethnic entrepreneurship' and 'women's entrepreneurship' from a family embeddedness perspective, we present a framework (Figure 1) illustrating that MWEs' entrepreneurship experiences are the result of a complex interplay of the constructs of 'being an Indian', being a woman' and 'being a new Australian. These constructs reinforce earlier findings (Jack and Anderson 2002; de Vries 2012), suggesting that behaviours of migrant entrepreneurs in host countries depend on their ethnic background and the host country's dynamics and context. As shown in Figure 1, our findings suggest that being an Indian can have both enabling and constraining effects on women's family dynamics, whereas being a woman is likely to have a constraining effect. In contrast, being a new Australian and being embedded in the host country's sociocultural context are likely to have an enabling effect that facilitates MWEs' desire for independence and autonomy and acts as a catalyst for entrepreneurship.

'Being an Indian' represents the influence of home country's cultural norms and beliefs which had a strong, dominant influence on MWEs and their partners, particularly in terms of their perceived strict gender roles which impose responsibilities for women to 'look after and take care of the family members' and 'make everyone happy', regardless of their involvement in their own business. We found that these prescribed gender roles contributed to their strong family orientation, which is reflected in their 'family-first' attitude and living in a joint family. Examples of strong orientation towards family in our data are represented by quotes such as, 'family always being the priority', 'important for wife to take care of the child', 'loving to live in extended families' and 'drawing on family members' help when in need'. Findings also reveal that more than half of the MWEs were living with extended family in-laws, uncles, aunts and cousins - as a joint family. This is in contrast to earlier findings of the joint family disappearing in India (Gupta 2005; Chadda and Deb 2013), as less than half 


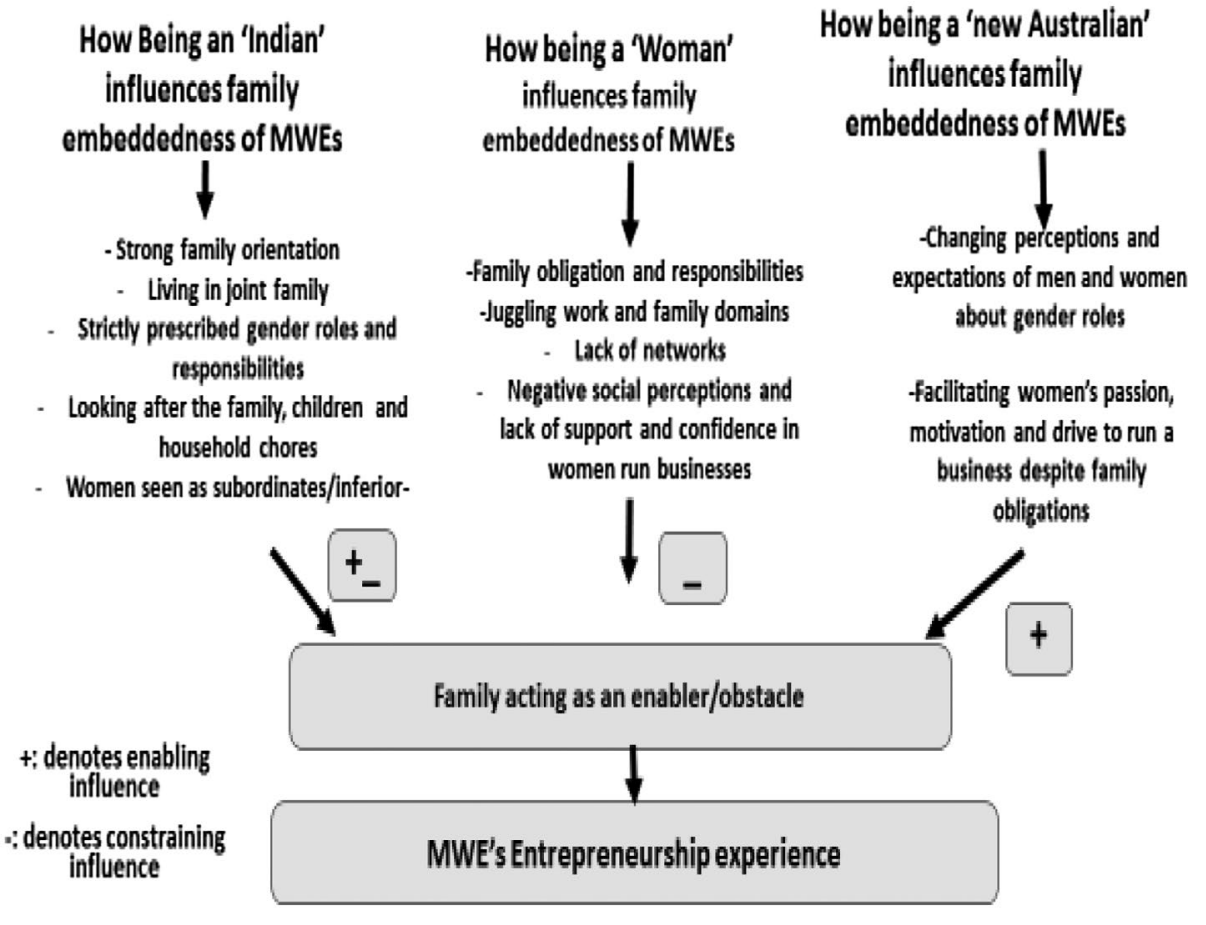

Figure 1. A framework explaining entrepreneurship experiences of Indian MWEs from a family embeddedness perspective.

of the participants in our sample were living independently. Further, as the participants were living in a host country where their extended families could not join them, it can be assumed that the percentage of joint families would be higher in their home country. This finding, therefore, highlights that joint families are still prevalent and have a strong influence on MWEs.

Further, in line with prior research, we found evidence that in Indian society, 'the masculine takes precedence'; women are expected to be different and weaker than men, 'generating and sustaining a hierarchical ordering which elevates the masculine and subordinates the feminine' (Marlow and McAdam 2012, 119) This is represented in the cases of some MWEs who despite being educated had to accept that 'women are inferior to men in status"needing protection' which led to their'dependence on men'. Such a finding supports earlier research that traits like conformity, obedience, dependence, submissiveness and self-denial are deeply ingrained in Indian women, along with the hierarchical structure in the family. These expectations result in the self-prescribed role of the dutiful daughter and wife and the devoted mother (Jeyaraj 2001, 144). MWEs' acceptance of and commitment to household responsibilities, regardless of them being entrepreneurs, in essence, highlights the male dominance and the influence of the Indian culture and values that make them obedient and submissive to men and conform to the prescribed roles and responsibilities (Jeyaraj 2001; Kantor 2002; Pio 2005). As a result, the majority of the women in our sample had a double workload - their business as well as their family - which reduced their energy and commitment and affected their productivity. 
Our findings further suggest that the strong influence of Indian culture and being an Indian has an impact on family dynamics, where the family can play a dual role by either acting as an enabler and/or an obstacle for women's entrepreneurial dreams. This finding is in line with recent research (Dhaliwal, Scott, and Hussain 2010; Azmat 2013). The majority of the women in our sample reported they had received family support that had helped them become an entrepreneur. For some, this family support was in the form of financial assistance, for others, it was having household responsibilities and children looked after, while for others, the support provided them with an opportunity to get out on their own. However, some women also reported experiencing the family as a barrier, particularly in terms of responsibilities and commitments, which meant that the women had to make trade-offs which, at times, not only created pressure on them but also threatened the sustainability of their businesses.

We found that 'being a woman' had a negative influence on their family embeddedness as entrepreneurs, as shown in Figure 1. The MWEs faced multiple gender-specific challenges in terms of family obligations, juggling work/life domains, the lack of a social network and a lack of confidence that women can run businesses. These challenges have been widely acknowledged in the literature (Amine and Staub 2009; Dhaliwal, Scott, and Hussain 2010; Azmat 2013; Langevang et al. 2015) and confirm the thesis of 'double disadvantage' which refers to the problems faced by women, first as immigrants and second as women (SmithHunter and Boyd 2004; Azmat 2013).

Our findings further suggest that embeddedness in a host society led to better integration of the entrepreneurs into the sociocultural context of the host country. The institutional context in Australia, as the second-ranked country for starting a business venture, is characterized by easier access to knowledge, finance, networks and technology as well as support systems assisting women entrepreneurs. In addition, the sociocultural context promotes the values of a society where a strong emphasis is placed on issues such as personal freedom, independence and aspirations as well as the sharing of household responsibilities between partners. In addition, the changing perceptions and expectations of both men and women about gender roles - in terms of sharing roles and responsibilities between partners - as a result of their integration into the mainstream culture play a major role in helping women face and adapt to the barriers emerging from families. Our study indicates the slow but visible changes in partners' perceptions regarding the home country's cultural norms and beliefs, and prescribed gender roles as a result of their gradual integration and embeddedness into the host country's sociocultural context. Some of the men in our study were starting to understand the notion of role-sharing and were engaging in household work to help their partners. However, the majority of the participants in our sample were still found to believe that women should be responsible for all the household chores and child-rearing responsibilities.

Although not perfect, Australia is regarded as a pioneer in women's social rights which can be attributed to the waves of feminism providing women's suffrage as well as equality with men in areas of work and general social standing, thus allowing women greater control of their lives (Lake 1999; State Library of Victoria 2015). The embeddedness and integration of MWEs in the Australian sociocultural context, therefore, helped in igniting their desire to break away from their home country's cultural norms and prescribed responsibilities to be more independent and have a better work/life balance and, most importantly, to be a part of the host society. Despite being motivated and having aspirations of freedom and 
autonomy, the women could not realize their entrepreneurial dreams in their home country. As women in India have been subject to centuries of exploitation and subjugation without being actively involved in the mainstream of development (Nagadevara 2009), their embeddedness in Australian host society acted as a catalyst for pursuing their entrepreneurial dreams. It facilitated their passion, strong desire for autonomy, freedom and independence to break away from the restrictions imposed by the home country's cultural norms that limited their freedom and autonomy and imposed specific responsibilities. In our sample, this is reflected in the prevalence of pull factors such as their desire for autonomy, their hard work, passion and motivation along with financial reasons as the primary motivators for most women to become an entrepreneur. The strong passion and determination of MWEs in our study were further instrumental in embedding the entrepreneurs in the host country's context, thus helping them adjust to the local culture, access finance and comprehend the local rules and regulations. Barriers such as the lack of social networks and issues with language and accents were also overcome. In contrast, some MWEs were pushed into entrepreneurship because they had struggled to find a job. Our findings, therefore, highlight the importance of social embeddedness and how it dissolves the division implicit in the pullpush logic offering additional insights into the phenomenon of entrepreneurship. The social embeddedness of MWEs also provides an explanation of more women in our sample being pulled into entrepreneurship, contrary to common perceptions which indicates women are generally pushed to be entrepreneurs.

Our findings suggest that although the MWEs in our sample were a heterogeneous group, differing in their age, experience and types of families, family embeddedness acted as a strong and uniting feature of homogeneity among them, through the interplay of MWEs being 'an Indian', 'a woman' and 'a new Australian'. However, we could identify certain nuances due to potential differences between the women. In addition to the construct of a joint family, the type of family in terms of 'being mothers' added more complexities in the lives of MWEs. Decreasing support from currently supportive family members was an added likelihood, with the expectation that mothers should 'give $100 \%$ time and effort to the child' after the birth of the child, as is reflected in the accounts of Participants 3, 4, 6 and Participant 8, whose circumstances changed over time after becoming a mother. Such nuances connect and relate to the constructs of 'being an Indian' and 'being a woman'. Further, we found that the better educated MWEs with a postgraduate degree (Participants, 4, 8, 9, 10 and 11) were involved in industries not specific to women, such as legal outsourcing, solar panelling and web designing, suggesting the role of education in their integration into the Australian sociocultural context and making them sufficiently confident to start their own business in diverse areas. Moreover, in terms of experiences, only three women (Participants, 8, 9 and 11) had previous experience of businesses which could be related to their education levels. The low number of women with previous experience in business indicates the climate in India where the social perceptions are not supportive enough for them to start a business of their own. Thus, there is a connection to the construct of 'being a new Australian' as an enabling force for their entrepreneurial experience. It further suggests the role of education in building the confidence and determination of MWEs to become entrepreneurs in Australia. 


\section{Theoretical implications}

This study has a number of theoretical implications. First, by focusing on MWEs and presenting a framework explaining their entrepreneurship experience from a family embeddedness perspective, our study adds to the literature on ethnic entrepreneurship and women entrepreneurship. Second, this is the first study to provide holistic insights into the phenomenon of Indian MWEs from a family embeddedness perspective, by drawing on perceptions of both the MWEs and their partners. In doing so, our findings confirm earlier results (Jack and Anderson 2002; de Vries 2012), suggesting that behaviours of migrant entrepreneurs in host countries depend on their ethnic background and the host country's dynamics and social contexts.

\section{Practical implications}

This study provides multiple policy implications for managers and practitioners. First, the findings highlight the significance of home country's culture and how 'being an Indian' affects MWEs' family dynamics. In particular, the study provides insights into the centrality of Indian culture, its strong influence on prescribed gender roles, the importance given to family, the existence of a male-dominated society where women are seen as weaker and inferior and the duality of family roles as being both enablers and/or obstacles for MWEs. The findings also signify the importance of MWEs' embeddedness in the host country's sociocultural context and how it can act as a catalyst driving their passion and motivation (pull factors), and contributing to the changing perceptions of gender roles of both men and women entrepreneurs. These insights are likely to be useful for policy-makers to better inform them about Indian MWEs, their idiosyncrasies and how policies can be formulated to facilitate their entrepreneurship in areas such as high-quality, affordable childcare services. Second, our framework has implications for policy-makers devising strategies to help women entrepreneurs integrate into a host society which can then facilitate their passion and motivation, pulling them towards entrepreneurship. Some of these strategies could include helping them establish networks with local counterparts to make them aware of egalitarian values and ways of establishing business in the host society, as well as developing their knowledge about local norms and language. Third, the framework would also be useful for MWEs and their partners. They can reflect on their roles and expectations, the influences of their home country's culture and, importantly, ways to integrate into the host country's culture and context, and focus on developing the pull factors to help overcome any barriers. Finally, although our findings are specific to the Indian context, the experiences of women in India are often relatively parallel to the experiences of women in South Asian countries that have a prevalent male-dominated culture.

\section{Limitations and directions for future research}

There are some limitations to our study which lead to future areas for research. As we explored the entrepreneurship experience of Indian MWEs in Australia, which is ranked the second most ideal place for women entrepreneurs with its supporting and favourable environment for women to start their businesses, findings are likely to be different in a host country that does not have such a supporting environment for women entrepreneurs. In 
addition, our data highlighted the impact of the embeddedness of MWEs in the sociocultural context of a host society; the influence of other contexts in a host country, such as their embeddedness in the legal and institutional environment, were not reported and could be explored in future studies.

Although our study has focused on reporting new dimensions in 'ethnic' and 'women's entrepreneurship' literature from a family embeddedness perspective, we are conscious that our study has predominantly focused on a group-level analysis of MWEs using the family embeddedness perspective, as per the requirements of a group-based dialogic introspection method, and has not looked into the nuances and potential differences between different women in detail. Future studies could draw a larger sample in different ethnicities in the South Asian region to identify potential nuanced differences. As MWEs are a heterogeneous group, studies could explore the nuances of potential differences between women in detail in areas such as education, type of family, age and experience of their entrepreneurship experience. Future research on MWEs reporting on more elaborate case descriptions of women's stories and experiences would also be useful in providing a better understanding of the different contextual factors that impact their experiences, as well as how they might have been changing over time. Despite certain limitations, our study is the first of its kind to provide insights into the under-researched topic of Indian MWEs and how their lived experiences are influenced by their family embeddedness, using both, a partner approach and multiple methods of investigation.

\section{Note}

1. 'Abla' is a Hindi word meaning helpless, referring to someone who is unable to defend oneself or to act without help. In India, women are generally viewed as abla.

\section{Disclosure statement}

No potential conflict of interest was reported by the authors.

\section{References}

Ahl, H. 2006. "Why Research on Women Entrepreneurs Needs New Directions." Entrepreneurship Theory and Practice 30 (5): 595-621.

Aldrich, H. E., and J. E. Cliff. 2003. “The Pervasive Effects of Family on Entrepreneurship: Toward a Family Embeddedness Perspective." Journal of Business Venturing 18 (5): 573-596.

Amine, L. S., and K. M. Staub. 2009. "Women Entrepreneurs in Sub-Saharan Africa: An Institutional Theory Analysis from a Social Marketing Point of View." Entrepreneurship and Regional Development 21 (2): 183-211.

Azmat, F. 2010. “Exploring Social Responsibility of Immigrant Entrepreneurs: Do Home Country Contextual Factors Play a Role?" European Management Journal 28 (5): 377-386.

Azmat, F. 2013. "Opportunities or Obstacles? Understanding the Challenges Faced by Migrant Women Entrepreneurs." International Journal of Gender and Entrepreneurship 5 (2): 198-215.

Azmat, F., and R. Rentschler. 2015. "Gender and Ethnic Diversity on Boards and Corporate Responsibility: The Case of the Arts Sector." Journal of Business Ethics. doi:10.1007/s10551-015-2707-0.

Basham, L. A. 2005. The Wonder That Was India. 3rd ed. London: Picador.

Basu, A. 1998. "An Exploration of Entrepreneurial Activity among Asian Small Business in Britain." Small Business Economics 10 (4): 313-326. 
Basu, A., and E. Altinay. 2002. "The Interaction between Culture and Entrepreneurship in London's Immigrant Businesses." International Small Business Journal 20 (4): 371-393.

Baycan-Levent, T. 2010. "Migrant Women Entrepreneurship in OECD Countries." In Open for Business: Migrant Entrepreneurship in OECD Countries, 227-254. Paris: OECD. doi:10.1787/978926409583012-en.

Beckers, P., and F. B. Blumberg. 2013. "Immigrant Entrepreneurship on the Move: A Longitudinal Analysis of First- and Second-Generation Immigrant Entrepreneurship in the Netherlands." Entrepreneurship \& Regional Development 25 (7-8): 654-691.

de Bruin, A., C. G. Brush, and F. Welter. 2006. "Introduction to the Special Issue: Towards Building Cumulative Knowledge on Women's Entrepreneurship." Entrepreneurship Theory and Practice 30 (5): 585-593.

Brush, C. G., and S. Y. Cooper. 2012. "Female Entrepreneurship and Economic Development: An International Perspective." Entrepreneurship \& Regional Development 24 (1-2): 1-6.

Budhwar, P., S. D. Saini, and J. Bhatnagar. 2005. "Women in Management in the New Economic Environment: The Case of India." Asia Pacific Business Review 11 (2): 179-193.

Calas, M., L. Smircich, and K. Bourne. 2009. “Extending the Boundaries: Reframing 'Entrepreneurship as Social Change'Through Feminist Perspectives." Academy of Management Review 34 (3): 552-569.

Chadda, R. K., and S. K. Deb. 2013. "Indian Family Systems, Collectivistic Society and Psychotherapy." Indian Journal of Psychiatry 55 (2): S299-S309.

Chiang, F., A. Low, and J. Collins. 2013. "Two Sets of Business Cards: Responses of Chinese Immigrant Women Entrepreneurs in Canada and Australia to Sexism and Racism." Cosmopolitan Civil Societies: An Interdisciplinary Journal 5 (2): 63-83.

Chirico, F., and M. Bau. 2014. "Is the Family an 'Asset' or 'Liability' for Firm Performance? The Moderating Role of Environmental Dynamism." Journal of Small Business Management 52 (2): 210-225.

Clark, K., and S. Drinkwater. 2010. "Recent Trends in Minority Ethnic Entrepreneurship in Britain." International Small Business Journal 28 (2): 136-146.

Collins, J. 1991. Migrant Hands in a Distant Land: Australia's Post-War Immigration. 2nd ed. Sydney: Pluto Press.

Collins, J., and A. Low. 2010. "Asian Female Immigrant Entrepreneurs in Small and Medium-sized Businesses in Australia." Entrepreneurship \& Regional Development 22 (1): 97-111.

Constance, L., D. Ip, J. Kitay, I. Phillips, and N. Tracy. 1991. Asian Entrepreneurs in Australia. Canberra: Australian Government Publishing Service.

Dana, L. P., ed. 2007. Handbook of Research on Ethnic Minority Entrepreneurship: A Co-evolutionary View on Resource Management. Cheltenham: Edward Elgar.

Dhaliwal, S., and P. Kangis. 2006. "Asians in the UK: Gender, Generations and Enterprise." Equal Opportunities International 25 (2): 92-108.

Dhaliwal, S., J. M. Scott, and J. Hussain. 2010. "Help or Hindrance? South Asian Women in the Family Firm." Electronic Journal of Family Business Studies 1 (4): 4-23.

Dhawan, N. 2005. "Women's Role Expectations and Identity Development in India." Psychology and Developing Societies 17 (1): 81-92.

Drori, I., B. Honig, and A. Ginsberg. 2006. “Transnational Entrepreneurship:Toward a Unifying Theoretical Framework." Academy of Management Conference, Best Paper Proceedings, Atlanta, GA.

Ensign, C. P., and P. R. Robinson. 2011. “Entrepreneurs Because They Are Immigrants, or Immigrants Because They Are Entrepreneurs? A Critical Examination of the Relationship between the Newcomers and the Establishment." Journal of Entrepreneurship 20 (1):33-53.

Essers, C., H. Doorewaard, and Y. Benschop. 2013. "Family Ties: Migrant Female Business Owners Doing Identity Work on the Public-Private Divide." Human Relations 66 (12): 1645-1665. doi:10.1177/0018726713486820.

Flood, G. 2003. The Blackwell Companion to Hinduism. Oxford: Blackwell.

Gender-GEDI Executive Report. 2013. A 17-country Pilot Analysis of the Conditions That Foster Highpotential Female Entrepreneurship. Global Entrepreneurship and Development Institute. http://www. thegedi.org.

Ghosh, P., and R. Cheruvalath. 2007. "Indian Female Entrepreneurs as Catalysts for Economic Growth and Development." The International Journal of Entrepreneurship and Innovation 8 (2): 139-148. 
Goyal, M., and J. Parkash. 2011. “Women Entrepreneurship in India-problems and Prospects."International Journal of Multidisciplinary Research 1 (5): 195-207.

Guba, E., and Y. Lincoln. 1981. Effective Evaluation. San Francisco, CA: Sage.

Gupta, D. 2005. "Whither the Indian Village: Culture and Agriculture in Rural India." Economic and Political Weekly 40 (8): 751-758.

Gutiérrez, R. P., D. M. Fuentes, and R. L. Ariza. 2014. "Strategic Capabilities and Performance in Womenowned Businesses in Mexico." Journal of Small Business Management 52 (3): 541-554.

Habbershon, T. G., and J. Pistrui. 2002. "Enterprising Families Domain: Family-influenced Ownership Groups in Pursuit of Transgenerational Wealth." Family Business Review 15: 223-237.

Hamilton, R., L. P. Dana, and C. Benfell. 2008. "Changing Cultures: An International Study of Migrant Entrepreneurs." Journal of Enterprising Culture 16 (I): 89-105.

Hiebert, D. 2002. "Economic Associations of Immigrant Self-employment in Canada." International Journal of Entrepreneurial Behaviour \& Research 8 (1/2): 93-112.

Huggins, R., and P. Thompson. 2014. “Culture, Entrepreneurship and Uneven Development: A Spatial Analysis." Entrepreneurship \& Regional Development: An International Journal 26 (9-10): 726-752.

Hughes, K. D., J. Jennings, C. Brush, S. Carter, and F. Welter. 2012. “Extending Women's Entrepreneurship Research in New Directions." Entrepreneurship Theory and Practice 36 (3): 429-442.

Jack, S. L., and A. R. Anderson. 2002. "The Effects of Embeddedness on the Entrepreneurial Process." Journal of Business Venturing 17 (5): 467-487.

Jamali, D. 2009. "Constraints and Opportunities Facing Women Entrepreneurs in Developing Countries." Gender in Management: An International Journal 24 (4): 232-251.

Jennings, J. E., and M. S. McDougald. 2007. “Work-family Interface Experiences and Coping Strategies: Implications for Entrepreneurship Research and Practice." Academy of Management Review 32: 747-760.

Jeyaraj, N. 2001. Women and Society. Madurai: Vanguard.

Kantor, P. 2002. "Gender, Microenterprise Success and Cultural Context: The Case of South Asia." Entrepreneurship Theory and Practice 26: 131-143.

Keating, E. 2014. Australia Ranked Second-best Place to Be a Female Entrepreneur. Accessed April 30. http://www.smartcompany.com.au/leadership/strategy/42238-australia-ranked-second-best-placeto-be-a-female-entrepreneur.html

Kelley, D., C. Brush, P. Greene, M. Herrington, A. Ali, and P. Kew. 2014. Special-report-women'sentrepreneurship, Global Entrepreneurship Monitor, 1-157.

Kleining, G., and T. Burkart. 2001. "Group-based Dialogic Introspection and Its Use in Qualitative Media Research." In Qualitative Research in Psychology, edited by M. Kiegelmann, 217-239. Schwangau: Ingeborg Huber.

Kloosterman, R., J. Van der Leun, and J. Rath. 1999. "Mixed Embeddedness: (In)Formal Economic Activities and Immigrant Businesses in the Netherlands." International Journal of Urban and Regional Research 23 (2): 252-266.

Kupferberg, F. 2003. "The Established and the Newcomers: What Makes Immigrant and Women Entrepreneurs So Special?" International Review of Sociology 13 (1): 89-104.

Lake, M. 1999. Getting Equal: The History of Australian Feminism. St Leonards: Allen \& Unwin.

Lane, B. 2014. Indians Now Our Top Migrants: The Australian. Accessed April 3. http://www.theaustralian. com.au/national-affairs/policy/indians-now-our-top-migrants/story-fn9hm1gu-1226430407750

Langevang, T., K. V. Gough, P.W. Yankson, G. Owusu, and R. Osei. 2015. “Bounded Entrepreneurial Vitality: The Mixed Embeddedness of Female Entrepreneurship." Economic Geography 91 (4): 449-473.

Marlow, S., and M. McAdam. 2012. "Gender and Entrepreneurship: Advancing Debate and Challenging Myths; Exploring the Mystery of the Under-performing Female Entrepreneur." International Journal of Entrepreneurial Behaviour and Research 19 (1): 114-124.

Marlow, S., and J. Swail. 2014. "Gender, Risk and Finance: Why Can't a Woman Be More like a Man? Entrepreneurship \& Regional Development 26 (1): 80-96.

Miles, M., and M. Huberman. 1994. Qualitative Data Analysis: An Expanded Sourcebook. 2nd ed. Thousand Oaks, CA: Sage.

Nagadevara, V. 2009. "Impact of Gender in Small Scale Enterprises: A Study of Women Entrepreneurs in India." International Journal of Business and Economics 9 (1): 111-117. 
Nimkoff, M. F. 2005. “The Family in India: Some Problems concerning Research on the Changing Family in India." In Family in India: Structure and Practice, edited by T. Patel, 71-80. Themes in Indian Sociology Series. Schwangau: Sage.

Pécoud, A. 2010. “What is Ethnic in an Ethnic Economy?" International Review of Sociology 20 (1): 59-76. Pio, E. 2005. "Knotted Strands: Working Lives of Indian Women Migrants in New Zealand." Human Relations 58 (10): 1277-1299.

Pio, E. 2007. "Ethnic Entrepreneurship among Indian Women in New Zealand: A Bittersweet Process." Gender, Work and Organization 14 (5): 409-432.

Pio, E., and C. Essers. 2014. "Professional Migrant Women Decentring Otherness: A Transnational Perspective." British Journal of Management 25 (2): 252-265.

Raijman, R., and M. Semyonov. 1997. “Gender, Ethnicity, and Immigration: Double Disadvantage and Triple Disadvantage among Recent Immigrant Women in the Israeli Labor Market." Gender and Society 11 (1): 108-125.

Rouse, J., and J. Kitching. 2006. Do Enterprise Support Programmes Leave Women Holding the Baby? London: Kingston University Research Repository. http://eprints.kingston.ac.uk/archive/00001083.

Sabah, S., L. A. Carsrud, and A. Kocak. 2014. “The Impact of Cultural Openness, Religion, and Nationalism on Entrepreneurial Intensity: Six Prototypical Cases of Turkish Family Firms." Journal of Small Business Management 52 (2): 306-324.

Shelton, L. M. 2006. "Female Entrepreneurs, Work-family Conflict, and Venture Performance: New Insights into the Work-family Interface." Journal of Small Business Management 44 (2): 285-297.

Shivani, S., S. K. Mukherjee, and R. Sharan. 2006. "Socio-cultural Influences on Indian Entrepreneurs: The Need for Appropriate Structural Interventions." Journal of Asian Economics 17: 5-13.

Singh, N., H. Zhao, and X. Hu. 2005. "Analyzing the Cultural Content of Web Sites: A Cross-national Comparison of China, India, Japan, and US." International Marketing Review 22 (2): 129-146.

Smallbone, D., and F. Welter. 2001. "The Distinctiveness of Entrepreneurship in Transition Economies." Small Business Economics 16 (4): 249-262.

Smith-Hunter, E. A., and L. R. Boyd. 2004. "Applying Theories of Entrepreneurship to a Comparative Analysis of White and Minority Women Business Owners." Women in Management Review 19 (1): $18-28$.

State Library of Victoria. 2015. Women's Rights Movements in Victoria. Accessed June 27. http://ergo.slv. vic.gov.au/explore-history/fight-rights/womens-rights/womens-rights-movement-victoria

Stromback, T., and R. Malhotra. 1994. Socio-economic Linkages of South Asian Immigrants with Their Country of Origin. Canberra: BIPR and Australian Government Publishing Service.

Terjesen, S., and A. Lloyd. 2015. The 2015 Female Entrepreneurship Index: An Analysis of the Conditions That Foster High-potential Female Entrepreneurship. Washington, DC: Global Entrepreneurship and Development Institute.

Tripathi, D. 1984. "Indian Business Houses and Entrepreneurship: A Note on Research Trends." Journal of Entrepreneurship 1 (1): 75-97.

Verduijn, K., and C. Essers. 2013. "Questioning Dominant Entrepreneurship Assumptions: The Case of Female Ethnic Minority Entrepreneurs." Entrepreneurship \& Regional Development 25 (7-8): 612-630.

Volery, T. 2007. "Ethnic Entrepreneurship: A Theoretical Framework."In Handbook of Research on Ethnic Minority Entrepreneurship: A Co-evolutionary View on Resource Management, edited by L. P. Dana, 30-41. Cheltenham: Edward Elgar.

de Vries, H.P. 2007. "Immigrant Entrepreneurship in New Zealand", Small Enterprise Conference, Auckland, New Zealand.

de Vries, H. P. 2012. “Do Indian Immigrant Entrepreneurs Residing in Different Host Countries Display the Same Behavioural Patterns?" Journal of Enterprising Communities: People and Places in the Global Economy 6 (2): 138-153.

Waldinger, R., H. Aldrich, and R. Ward. 1990. "Opportunities, Group Characteristics and Strategies." In Ethnic Entrepreneurs: Immigrant Business in Industrial Societies, edited by R. Waldinger, H. Aldrich and R. Ward, 13-48. London: Sage.

Watts, N., A. Trlin, C. White, and N. North. 2007.“Immigrant Cultural Capital in Business: The New Zealand Experience." Handbook of Research on Ethnic Minority Entrepreneurship: A Co-evolutionary View on Resource Management, edited by L. P. Dana, 729-743. Cheltenham: Edward Elgar. 
Welter, F. 2011. "Contextualizing Entrepreneurship - Conceptual Challenges and Ways Forward." Entrepreneurship Theory and Practice 35 (1): 165-184.

Welter, F., and D. Smallbone. 2010. "Women's Entrepreneurship in a Transition Context." In Women's Entrepreneurship and Growth Influences: An International Perspective, edited by C. Brush, E. Gatewood, C. Henry and A. De Bruin, 96-117. Cheltenham: Edward Elgar.

Witt, H. 2010. "Group-based Dialogic Introspection,". In Handbuch Qualitative Forschung in der Psychologie, edited by G. Mey, and K. Mruck, 252-262. Wiesbaden:VS Verlag für Sozialwissenschaften (Published in an Abbreviated Form and in German). 